\title{
SISTEM BAGI HASIL DALAM PERJANJIAN WARALABA (FRANCHISE) PERSPEKTIF HUKUM ISLAM
}

\author{
Puji Sulistyaningsih \\ Fakultas Hukum Universitas Muhammadiyah Magelang \\ Email: pujisulistyaningsih@yahoo.com \\ Heniyatun \\ Fakultas Hukum Universitas Muhammadiyah Magelang \\ Email: heni.suprapto@yahoo.co.id \\ Heni Hendrawati \\ Fakultas Hukum Universitas Muhammadiyah Magelang \\ Email: henihendrawati22@yahoo.com
}

\begin{abstract}
Abstrak
Franchise (waralaba) merupakan sebuah model bisnis yang telah terbukti berhasil dan banyak pengusaha menggunakan model bisnis tersebut saat ini. Dalam hukum ekonomi Islam, Waralaba masih dianggap suatu hal baru. Meskipun demikian, hal tersebut tidak menyurutkan para pengusaha untuk menekuninya karena waralaba lebih menguntungkan dan tidak bertentangan dengan konsep Syariah. Salah satu ciri khas waralaba adalah adanya royalty, yaitu pembagian keuntungan antar franchisor dan franchisee dengan ketentuan yang telah disepakati oleh kedua belah pihak. Adapun dalam waralaba Syariah, sistem pembagian keuntungannya menggunakan sistem bagi hasil. Permasalahan yang akan dikaji dalam penelitian ini adalah bagaimana sistem bagi hasil dalam perjanjian waralaba perspektif hukum Islam, dan bagaimana cara mengatasi kendala dalam sistem bagi hasil dalam perjanjian waralaba perspektif hukum Islam. Metode yang digunakan dalam penelitian ini yaitu menggunakan metode pendekatan yuridis normatif, dan menggunakan spesifikasi penelitian deskriptif analitis. Adapun penarikan sampelnya menggunakan purposive sampling. Alat penelitian meliputi studi kepustakaan dan wawancara. Selanjutnya dianalisis dengan metode kualitatif. Hasil penelitian menunjukkan pembagian keuntungan dalam perjanjian waralaba perspektif hukum Islam menggunakan sistem bagi hasil, dengan persentase yang bervariatifyaitu: 50:50 atau 60:40 tergantung kesepakatan para pihak (franchisor dan franchisee). Kendala yang sering terjadi dalam perjanjian waralaba, yaitu ketika terjadi kerugian, ketidakseimbangan antara prestasi yang diberikan dengan keuntungan (bagi hasil), dan adanya pembagian keuntungan yang kurang transparan. Penyelesaian kendala-kendala tersebut terutama dalam pembagian keuntungan biasanya diselesaikan secara musyawarah mufakat, pembayaran ganti rugi, atau jika tidak tercapai dapat melalui arbitrase.
\end{abstract}

Kata kunci: Bagi Hasil; Perjanjian Waralaba; Hukum Islam 
Franchise is a business model that has proven successfully, that is why many entrepreneurs using this business model. In the Islamic economic law, franchise is still considered a novelty. Nevertheless, this should not discourage entrepreneurs to persevere that business because franchise more profitable and it seems not contradict with the Sharia Law. One of the franchise's characteristic is the royalty; that is the profit-sharing between franchisor and franchisee based on the agreed provision by both parties. Sharia franchise, however, applies Profit Sharing System. The Issues examined in this research are how the Profit Sharing System of Franchise agreement in Islamic Perspective applied and how to solve the problems of Profit Sharing system of Franchise agreement in Islamic Perspective. This research used juridical normative as a method of analysis, specifically descriptive analytic research. The samples gathered by using purposive sampling and the optimalized of research tools such as literature study and interview. Then, the data analyzed using qualitative method. According to the result of this study, Profit Sharing System in Islamic Perspective is applied in Franchise agreement with various percentage of 50:50 or 60:40 depending on the agreement of both parties (franchisor and franchisee). The common problems of franchise agreement are the imbalance between performance and the profit sharing, also the lack of transparency in profit sharing. The problems, especially in profit sharing, usually settled by deliberative consensus, compensation payment, or arbitration when there is no agreement.

Keywords: Profit Sharing; Franchise Agreement; Islamic Law.

\section{A. LATAR BELAKANG}

Persaingan perdagangan global yang semakin ketat sekarang ini memerlukan sistem pemasaran yang mendukung, namun sering terjadi biaya untuk pemasaran terlalu tinggi sehingga timbul alternatif untuk menghemat biaya dengan melakukan pemasaran melalui salah satu cara yang efektif dan efisien, salah satunya yaitu dengan sistem waralaba. Waralaba pada dasarnya adalah suatu perjanjian mengenai metode pendistribusian barang dan/atau jasa kepada konsumen.

Salah satu pendukung pesatnya pertumbuhan ekonomi di Indonesia adalah berkembangnya sistem pemasaran dalam berbagai bidang usaha, hal ini menunjukkan semakin tingginya daya saing antar industri perdagangan dalam melakukan pemasaran, juga industri barang dan/atau jasa. Salah satu sistem pemasaran yang marak dan mulai diminati serta telah berhasil menarik perhatian para pengusaha lokal untuk bersaing dengan pengusaha asing adalah sistem waralaba atau franchise. Waralaba merupakan salah satu daya tarik yang tinggi bagi calon pengusaha yang ingin memiliki usaha mereka sendiri, tetapi bukan sepenuhnya milik mereka.

Bisnis dengan sistem waralaba ini, merupakan suatu kegiatan usaha dari para pengusaha kecil yang ada di Indonesia agar dapat berkembang secara wajar dengan menggunakan resep, teknologi, kemasan, manajemen pelayanan, merek dagang/ jasa pihak lain dengan membayar sejumlah royalty berdasarkan lisensi waralaba. Di samping itu pengembangan sumber daya manusia yang berkualitas juga merupakan suatu hal yang penting, oleh karena itu dengan melalui pelatihan keterampilan dalam menjalankan usaha waralaba yang diselenggarakan oleh pihak pemberi lisensi 
waralaba, para pengusaha kecil tidak perlu bersusah payah menciptakan sendiri sistem bisnis, cukup dengan menyediakan modal kemitraan usaha, membayar royalty, dengan memanfaatkan sistem bisnis waralaba asing melalui lisensi bisnis.

Perjanjian waralaba merupakan suatu tindakan hukum yang menimbulkan hak dan kewajiban bagi masing-masing pihak. Melalui perjanjian waralaba, franchisor memberikan hak kepada franchisee sebagai mitra usahanya untuk menjalankan usaha di bidang yang sama dengan menggunakan merek dagang atau nama dagang dan hak milik intelektual lainnya dengan menjaga standar kualitas dan reputasi franchisor sehubungan dengan penggunaan merek dari barang dan/atau jasa yang diperjanjikan tersebut (Salim HS, 2003: 165).

Pengaturan hak dan kewajiban franchisor dan franchisee harus jelas, seimbang dan memiliki batas-batas tertentu agar di dalam pelaksanaannya tidak mengakibatkan kesewenang-wenangan salah satu pihak. Para pihak yang terikat oleh hak dan kewajiban tersebut selain memperhatikan hak dan kewajiban mereka sebagai pihak-pihak terikat dalam perjanjian waralaba agar memenuhi ketentuanketentuan mengenai peraturan waralaba yang terdapat dalam Peraturan Pemerintah Nomor 42 Tahun 2007 Tentang Waralaba sehingga hak dan kewajiban para pihak tidak melanggar ketentuan mengenai waralaba dan sesuai dengan ketentuan yang berlaku, hal ini merupakan tanggung jawab para pihak untuk mentaati hukum yang berlaku meskipun mereka bebas menetukan isi dari perjanjian yang mereka buat. Salah satu isi dari perjanjian itu adalah tentang pembagian royalty antara pewaralaba dan terwaralaba. Pembayaran royalty merupakan salah satu ciri dari waralaba.

Waralaba juga dikenal di dalam konsep Syariah, bahwa franchise merupakan pembelian HKI yang berupa merek dagang, penemuan dan ciri khas produk/menejemen usaha sebagai hak yang dimiliki franchisor. Apabila diperhatikan dari sudut bentuk perjanjian yang diadakan oleh franchisor dengan franchise dapat dikemukakan bahwa perjanjian itu sebenarnya merupakan pengembangan dari bentuk kerja sama (syarikah). Dikatakan merupakan bentuk pengembangan dari kerja sama, sebab dengan adanya perjanjian franchise itu maka secara otomatis antara franchisor dengan franchisee terbentuk hubungan kerja sama untuk waktu tertentu (sesuai dengan perjanjian). Kerja sama tersebut dimaksudkan untuk memperoleh keuntungan bagi kedua belah pihak.

Menurut hukum Islam bahwa perjanjian franchise tidak bertentangan dengan Syariah Islam. Tentunya dengan catatan bahwa objek perjanjian franchise tersebut tidak merupakan hal yang dilarang dalam Syariah Islam. Apabila obyek franchise merupakan hal yang dilarang dalam Syariah Islam (misalnya, makanan dan minuman yang haram) maka otomatis perjanjian tersebut bertentangan dengan Syariah Islam (Suhrawardi, 2004: 169).

Konsep Syariah waralaba setara dengan sistem sewa menyewa atau Ijārah karena dijelaskan bahwa dalam sistem waralaba, franchisor berkewajiban memberikan bimbingan kepada franschisee. Bimbingan tersebut meliputi pelatihan teknik menghasilkan produk dan pelatihan tentang manajemen produk yang dihasilkan. Oleh karena itu, franchisor berhak untuk menerima pembayaran dari 
franchisee. Penyewa berkewajiban membayar jasa pelatih yaitu franchisor. Pembayaran jasa itu dalam Islam disebut sebagai upah. Hal ini sesuai dengan sabda Nabi Muhammad Saw, dari Ibn Umar Ra., bahwa Rasulullah Saw. bersadba: "berikanlah upah kepada orang yang kamu pakai sebelum kering keringatnya" (Suhrawardi, 2004: 171).

Setiap perjanjian waralaba mempunyai ketentuan masing-masing mengenai royalty, baik dalam konsep hukum perdata maupun hukum Islam. Pada hukum Perdata biasanya pembagian royalty menggunakan sistem persentase, besarnya persentase telah ditetapkan oleh pewaralaba dan telah dicantumkan dalam isi perjanjian, sehingga pembagian keuntungan itu telah menjadi kesepakatan bagi para pihak. Namun dalam konsep hukum Islam sistem pembagian keuntungannya berbeda dengan konsep yang digunakan hukum perdata, yaitu dalam hukum Islam dikenal dengan sistem bagi hasil. Pembagian keuntungan dalam bisnis waralaba Syariah, misalnya yang telah dilakukan di Kebab Turki Babarafi pembagian keuntungannya dengan menggunakan sistem 50:50 dan telah ditentukan oleh pihak pewaralaba. Di dalam sistem bagi hasil ini sebelum para pihak melaksanakan perjanjian, sebelumnya mereka melakukan penawaran mengenai besarnya keuntungan yang akan diperoleh kedua belah pihak hingga tercapai kesepakatan.

Berdasarkan uraian tersebut di atas maka penulis tertarik untuk mengkaji tentang Sistem Bagi Hasil dalam Perjanjian "Franchise" (Waralaba) Perspektif Hukum Islam.

Berdasarkan uraian latar belakang tersebut di atas rumusan permasalahan yang menjadi kajian pokok dalam penelitian ini, yaitu:

1. Bagaimana sistem bagi hasil dalam perjanjian waralaba perspektif hukum Islam?

2. Apa kendala pada sistem bagi hasil dalam perjanjian waralaba perspektif hukum Islam dan bagaimana penyelesaiannya?

\section{B. METODE PENELITIAN}

Metode pendekatan yang digunakan dalam penelitian ini adalah yuridis normatif, yaitu dilakukan dengan cara meneliti bahan pustaka atau data sekunder yang bersifat hukum (Soerjono, 2005: 264) yang digunakan menjadi acuan untuk melakukan kajian yuridis tentang sistem bagi hasil dalam perjanjian waralaba perspektif hukum Islam.

Bahan penelitian yang digunakan ada dua jenis data, yaitu data primer yang diperoleh secara langsung dari hasil penelitian lapangan (field research). Penelitian lapangan ini di maksudkan untuk memperoleh data yang berhubungan dengan masalah yang di teliti dan data sekunder di peroleh dari penelitian kepustakaan. Bahan hukum dalam penelitian ini terdiri dari bahan hukum primer dan bahan hukum sekunder.

Teknik pengambilan sampel dengan menggunakan Non Random Sampling, di mana setiap obyek atau individu atau gejala yang memenuhi syarat tidak mempunyai kesempatan yang sama untuk menjadi sampel. Alasan praktis dan ekonomis, 
menjadikan purposive sampling sebagai teknik untuk mengambil sampel berdasarkan pada ciri-ciri, sifat-sifat atau karakteristik tertentu yang mempunyai hubungan dengan permasalahan yang sedang diteliti (Soemitro, 1994: 51). Subyek yang diambil sebagai sampel adalah waralaba syariah: 1) Kebab Turki Babarafi; dan 2) Lembaga Pendidikan Quantum Student.

Adapun teknik pengumpulan data melalui studi kepustakaan, penulis mempelajari, mengolah dan menelaah bahan-bahan hukum, baik literatur maupun peraturan perundang-undangan yang berkaitan dengan penelitian ini guna mendapatkan landasan teori, dan wawancara/interview adalah cara untuk memperoleh informasi dengan bertanya langsung kepada responden.

Data primer maupun data sekunder, selanjutnya diolah dan dianalisis dengan menggunakan analisis kualitatif. Analisis kualitatif adalah suatu tata cara penulisan yang menghasilkan data deskriptif analitis, yaitu apa yang dinyatakan oleh responden secara tertulis atau lisan juga perilaku yang nyata yang diteliti dan dipelajari sebagai sesuatu yang utuh (Soerjono, 2005: 36).

\section{PEMBAHASAN}

1. Tinjauan Umum

\section{a. Perjanjian Berdasarkan KUHPerdata}

Berdasarkan Pasal 1313 KUHPerdata perjanjian adalah suatu perbuatan dengan satu orang atau lebih mengikatkan dirinya terhadap satu orang lain atau lebih. Pengertian perjanjian dalam Pasal 1313 KUHPerdata tersebut banyak mendapatkan kritikan dari para sarjana karena mengandung banyak kelemahan. Pertama, hanya menyangkut perjanjian sepihak saja, yaitu dapat dilihat dari perkataan "satu orang atau lebih mengikatkan diri terhadap satu orang atau lebih". Kata "mengikatkan" merupakan kata kerja yang sifatnya hanya datang dari satu pihak saja, sehingga ada kesan seolah-olah hanya merupakan perjanjian sepihak. Adapun perjanjian yang dimaksud dalam Pasal 1313 KUH Perdata tersebut juga meliputi perjanjian timbal balik. Kedua, Pasal 1313 KUH Perdata juga tidak menyebutkan apa yang menjadi tujuan mengadakan perjanjian, sehingga tidak jelas untuk apa para pihak itu mengikatkan dirinya. Ketiga, pengertian perjanjian terlalu luas. Hal ini ditemukan dalam kalimat yang berbunyi, "suatu perbuatan", kata perbuatan di sini dapat mencakup semua perbuatan, padahal yang dimaksud adalah perbuatan hukum, yaitu perbuatan yang mempunyai akibat hukum. Selain itu perbuatan di sini dapat juga meliputi perbuatan hukum dan perbuatan melawan hukum, sehingga apabila hanya disebutkan perbuatan saja maka zaakwaarneming dan onrechtmatige daad juga termasuk di dalamnya. Kelemahan selain ketiga kelemahan tersebut di atas adalah yaitu tidak mengandung konsensus (Salim, 2002: 160).

Berdasarkan beberapa kelemahan tersebut di atas, maka para pakar hukum kemudian membuat definisi mengenai perjanjian. Menurut Subekti (2004: 1) "perjanjian adalah suatu peristiwa di mana seorang berjanji kepada seorang lain atau di mana dua orang itu saling berjanji untuk melaksanakan sesuatu hal". Menurut Van Dunne yang diartikan dengan perjanjian adalah "suatu hubungan hukum antara dua 
pihak atau lebih berdasarkan kata sepakat untuk menimbulkan akibat hukum" (dalam Salim, 2002: 161). Menurut Sudikno (2003: 118), "perjanjian itu adalah merupakan hubungan hukum antara dua orang yang bersepakat untuk menimbulkan akibat hukum". Adapun menurut Kartini, perjanjian adalah salah satu sumber perikatan, yang menciptakan kewajiban pada salah satu atau lebih pihak dalam perjanjian. Kewajiban yang dibebankan pada debitur dalam perjanjian, memberikan hak pada pihak kreditur dalam perjanjian untuk menuntut pelaksanaan prestasi dalam perikatan yang lahir dari perjanjian tersebut (Kartini, 2010: 91).

Berdasarkan beberapa definisi di atas dapat disimpulkan, kata "hubungan hukum" mempertegas makna bahwa hubungan antara para pihak dalam perjanjian merupakan hubungan hukum yang menimbulkan akibat hukum, menimbulkan pula hak dan kewajiban, sehingga apabila salah satu pihak melanggarnya maka si pelanggar akan dikenakan sanksi. Berbeda dengan rumusan dalam Pasal 1313 KUHPerdata yang ternyata menegaskan bahwa perjanjian mengikatkan dirinya terhadap orang lain. Ini berarti dari suatu perjanjian lahirlah kewajiban atau prestasi dari satu atau lebih orang (pihak) kepada satu atau lebih orang (pihak) lainnya yang berhak atas prestasi tersebut. Hal ini akan memberikan konsekuensi hukum bahwa dalam suatu perjanjian akan selalu ada dua pihak, yaitu satu pihak yang wajib berprestasi (debitur) dan pihak lainnya adalah pihak yang berhak atas perstasi tersebut (kreditur). Masing-masing pihak tersebut dapat terdiri dari satu orang atau lebih, bahkan dengan berkembangnya ilmu hukum, pihak tersebut dapat juga terdiri dari satu atau lebih badan hukum (Salim, 2003: 92).

Selanjutnya Pasal 1338 KUHPerdata ayat (1) menyebutkan bahwa "semua perjanjian yang dibuat secara sah berlaku sebagai undang-undang bagi mereka yang membuatnya". Bedasarkan ketentuan tersebut, maka dapat dipahami bahwa kedua pihak yang melakukan perjanjian terikat dalam suatu hubungan hukum yang mereka buat bersama. Suatu perjanjian dikatakan sah, apabila memenuhi ketentuan yang diatur dalam Pasal 1320 KUHPerdata. Ada empat ketentuan utama yang harus dipenuhi dalam setiap perjanjian, yaitu: a) kesepakatan; b) kecakapan; c) suatu hal tertentu; dan d) suatu sebab yang halal.

Kesepakatan yang dimaksud dalam Pasal 1320 KUHPerdata adalah persesuaian pernyataan kehendak antara satu orang atau lebih dengan pihak lainnya, dengan perkataan lain, sepakat terjadi apabila ada persesuaian kehendak secara timbal balik di antara kedua belah pihak. Oleh karena itu para pihak yang mengadakan perjanjian harus bersepakat, setuju mengenai hal-hal yang pokok dari perjanjian yang diadakan. Pengertian sepakat tersebut dilukiskan sebagai pernyataan kehendak yang disetujui (overeenstemmende wilsverklaring) antara para pihak. Pernyataan pihak yang menawarkan dinamakan tawaran (offerte). Pernyataan pihak yang menerima tawaran dinamakan akseptasi/acceptatie (Darus, 2001: 74). Suatu perjanjian dikatakan tidak mengandung kesepakatan apabila di dalamnya terdapat cacat kehendak (wilsgebrek), yaitu adanya unsur-unsur paksaan (dwang), kekhilafan (dwaling) dan penipuan (bedrog) (Pasal 1321 KUHPerdata). Adanya unsur paksaan yaitu apabila paksaan itu mengenai badan (fisik) dan terhadap jiwa (psikis). 
Kekhilafan/kekeliruan dapat terjadi karena keliru terhadap orang atau keliru terhadap barang. Unsur penipuan terjadi apabila suatu pihak dengan sengaja memberikan keterangan yang tidak benar.

Adanya kecakapan untuk membuat perikatan, secara yuridis diatur dalam Pasal 1329 KUHPerdata dan Pasal 1330 KUHPerdata. Pasal 1329 KUHPerdata menyebutkan bahwa setiap orang adalah cakap untuk membuat perikatan. Selanjutnya Pasal 1330 KUHPerdata menyatakan bahwa orang yang tidak cakap yaitu: 1) orang yang belum dewasa; 2) mereka yang ditaruh di bawah pengampuan; dan 3) orang-orang perempuan dalam hal-hal yang ditetapkan oleh undang-undang. Dalam perkembangannya, khusus untuk ketentuan ketiga mengenai perempuan telah dicabut dan digantikan dengan ketentuan yang ada dalam Undang-Undang No.1 Tahun 1974 Tentang Perkawinan sebagaimana yang diatur dalam Pasal 31 jo Surat Edaran Mahkamah Agung (SEMA) Nomor 3 Tahun 1963.

Pasal 31 Undang-undang Nomor 1 Tahun 1974 Tentang Perkawinan Ayat (1) dan (2) menyatakan bahwa: "1) Hak dan kedudukan istri adalah seimbang dengan hak dan kedudukan suami dalam kehidupan berumah tangga dan pergaulan hidup bersama dalam masyariahat; dan 2) Masing-masing pihak berhak untuk melakukan perbuatan hukum." Adapun SEMA Nomor 3 tahun 1963 menyebutkan: "MA-RI menganggap tidak berlaku lagi ketentuan di dalam KUHPerdata, antara lain Pasal 108 dan Pasal 110 KUHPerdata tentang wewenang seorang istri untuk melakukan perbuatan hukum dan untuk menghadap di muka pengadilan tanpa ijin atau bantuan suami". Berdasarkan hal tersebut maka tidak ada lagi perbedaan antara Warga Negara Indonesia perempuan dan laki-laki dalam membuat suatu perjanjian.

Suatu perjanjian juga harus mempunyai objek (bepaald onderwerp) tertentu, sekurang-kurangnya dapat ditentukan bahwa objek tertentu itu dapat berupa benda yang sekarang ada dan yang akan ada di kemudian hari (Pasal 1333 KUH Perdata). Maksud ketentuan adalah obyek atau barang yang diperjanjikan haruslah ditentukan, untuk dapat menetapkan kewajiban-kewajiban dari masing-masing pihak berjanji. Barang yang dimaksudkan dalam suatu perjanjian paling sedikit harus ditentukan jenisnya. Suatu hal tertentu dibuat guna menentukan agar hak dan kewajiban kedua belah pihak sesuai dengan apa yang diperjanjikan, untuk mencegah timbulnya perselisihan. Pada Pasal 1320 Ayat (3) KUHPerdata dinyatakan, yang dapat menjadi obyek perjanjian adalah suatu hal tertentu. Suatu hal tertentu adalah pokok atau obyek yang merupakan prestasi yang harus dipenuhi dalam suatu perjanjian, di mana obyek itu harus cukup jelas atau paling tidak ditentukan jenisnya, sedangkan jumlahnya tidak harus disebutkan, asal dapat dihitung atau ditetapkan. Hal tertentu tersebut tidak harus bersifat kebendaan, tetapi dapat juga berupa jasa untuk melakukan atau tidak melakukan sesuatu, yang pasti harus diperinci dengan jelas.

Selain itu, perjanjian sah karena sebab (causa) yang halal. Undang-Undang tidak memberikan pengertian mengenai hal ini. Menurut yurisprudensi yang ditafsirkan dengan kausa adalah isi atau maksud dari perjanjian. Melalui kausa, di dalam praktik maka ia merupakan upaya untuk menempatkan perjanjian di bawah pengawasan hakim (Darus, 2001: 61). Oleh karena undang-undang tidak menjelaskan secara tegas 
tentang suatu sebab yang halal, maka Pasal 1335 dan Pasal 1337 KUHPerdata dapat ditafsirkan secara a contrario. Pasal 1337 KUH Perdata hanya menjelaskan mengenai apa yang dimaksud dengan sebab terlarang, ialah sebab yang dilarang undangundang atau berlawanan dengan kesusilaan baik atau ketertiban umum. Oleh karena itu perjanjian yang dibuat dengan sebab yang demikian tidak mempunyai kekuatan (Pasal 1335 KUHPerdata). Jadi yang dimaksud sebab yang halal adalah sebab yang tidak dilarang oleh undang-undang, kesusilaan atau ketertiban umum, sedangkan yang dimaksud dengan sebab adalah tujuannya. Suatu sebab yang halal mengandung arti bahwa perjanjian tersebut dibuat dan dilaksanakan bedasarkan peraturan perundang-undangan yang berlaku dan bukan merupakan tindakan yang dilarang oleh undang-undang. Suatu sebab yang halal dimaksudkan sebagai perjanjian harus memiliki tujuan yang jelas dan nyata.

Syarat-syarat sahnya perjanjian tersebut di atas, dapat dibedakan menjadi dua bagian yaitu terdiri dari syarat subjektif dan objektif. Syarat subjektif terdapat dalam syarat pertama dan kedua (kesepakatan dan kecakapan), karena melekat pada diri orang yang menjadi subyek perjanjian, apabila tidak terpenuhi maka perjanjian itu dapat dibatalkan oleh salah satu pihak. Adapun syarat objektif terdapat dalam dua syarat yang terakhir (hal tertentu dan suatu sebab yang halal), apabila syarat objektif tidak terpenuh maka perjanjian tersebut batal demi hukum.

\section{b. Perjanjian Menurut Hukum Islam}

Istilah perjanjian dalam hukum Islam disebut akad. Kata akad berasal dari kata $a l$-'aqdu, yang berarti mengikat, menyambung atau menghubungkan. Ada beberapa definisi tentang akad yaitu: 1) Berdasarkan Pasal 262 Mursyid al-Hairan, akad merupakan pertemuan ijab yang diajukan oleh salah satu pihak dengan kabul dari pihak lain yang menimbulkan akibat hukum pada objek akad. 2) Menurut Syamsul Anwar, akad adalah pertemuan ijab dan kabul sebagai pernyataan kehendak dua pihak atau lebih untuk melahirkan suatu akibat hukum pada objeknya (Anwar, 2007: 68). Kedua definisi tersebut memperlihatkan bahwa, akad merupakan keterkaitan atau pertemuan ijab dan kabul yang berakibat timbulnya akibat hukum. Ijāb, adalah penawaran yang diajukan oleh salah satu pihak, dan qabūl artinya jawaban persetujuan yang diberikan mitra akad sebagai tanggapan terhadap penawaran pihak yang pertama.

Akad tidak terjadi apabila pernyataan kehendak masing-masing pihak tidak terkait satu sama lain karena akad adalah keterkaitan kehendak kedua pihak yang tercermin dalam ijab dan kabul (Anwar, 2007: 69). Akad merupakan tindakan hukum dua pihak karena akad adalah pertemuan ijab yang mempresentasikan kehendak dari satu pihak dan kabul kehendak pihak lain. Tindakan hukum satu pihak, seperti janji memberi hadiah, wasiat, wakaf, atau pelepasan hak, bukanlah akad, karena tindakantindakan tersebut tidak merupakan tindakan dua pihak dan karenanya tidak memerlukan kabul. Akad bertujuan untuk melahirkan suatu akibat hukum. Lebih tegas lagi tujuan akad adalah maksud bersama yang dituju dan yang hendak diwujudkan oleh para pihak melalui pembuatan akad. Akibat hukum dari akad dalam hukum Islam disebut hukum akad (Anwar, 2007: 69). Dengan demikian dalam suatu 
akad terkandung tiga unsur (Dewi, 2001: 48), yaitu: a) adanya pertalian ijab dan kabul; b) dibenarkan oleh syariat; dan c) mempunyai akibat hukum terhadap objeknya. Akad merupakan salah satu dari tindakan hukum. Adanya akad akan menimbulkan akibat hukum terhadap objek hukum yang diperjanjikan oleh para pihak dan juga memberikan konsekuensi hak dan kewajiban yang mengikat para pihak.

Masing-masing unsur (rukun) yang membentuk akad di atas memerlukan syarat-syarat agar unsur tersebut dapat berfungsi membentuk akad. Tanpa adanya syarat-syarat dimaksud, rukun akad tidak dapat membentuk akad. Syarat-syarat dimaksud dinamakan syarat-syarat terbentuknya akad (Pasaribu dan Lubis, 2004: 4) meliputi: a) tamyiz; b) berbilang pihak; c) persesuaian ijab dan kabul; d) kesatuan majelis akad; e) objek akad dapat diserahkan; f) objek akad tertentu atau dapat ditentukan; d) objek akad dapat ditransaksikan (berupa benda bernilai); dan e) tujuan akad tidak bertentangan dengan syariah.

Suatu akad menjadi sah apabila rukun-rukun dan syarat-syarat tersebut dipenuhi, dan menjadi tidak sah apabila rukun dan syaratnya tidak dipenuhi. Akan tetapi, oleh karena syarat-syarat akad itu beragam jenisnya, maka kebatalan dan keabsahan akad menjadi bertingkat-tingkat sesuai dengan sejauh mana rukun dan syarat-syarat itu terpenuhi (Anwar, 2007: 224). Ketentuan ini dapat dirincikan sebagai berikut (Anwar, 2007: 246-256):

a. Akad Batil, ahli-ahli hukum Hanafi mendefinisikan akad batil adalah akad yang secara syariat tidak sah pokok dan sifatnya. Akad yang pokoknya tidak memenuhi ketentuan syariah dan karena itu tidak sah adalah akad yang tidak memenuhi seluruh rukun dan syarat terbentukanya akad. Apabila salah satu saja tidak terpenuhi, maka akad itu disebut akad batil yang tidak ada wujudnya. Apabila pokoknya tidak sah, otomatis tidak sah sifatnya;

b. Akad Fāsid, menurut ahli-ahli hukum Hanafi, adalah akad yang menurut syariah sah pokoknya, tetapi tidak sah sifatnya. Perbedaannya dengan akad batil adalah bahwa akad batil tidak sah baik pokok maupun sifatnya. Adapun akad fasid adalah akad yang telah memenuhi rukun dan syarat pembentukan akad, akan tetapi tidak memenuhi syarat keabsahan akad;

c. Akad Mauqūf yang berarti terhenti, tergantung atau dihentikan. Akad Mauqū $f$ adalah akad yang sah karena sudah memenuhi rukun dan syarat terbentukanya maupun syarat keabsahannya, namun akibat hukumnya belum dapat dilaksanakan. Sebab sebelum dapat dilaksanakan, akibatakibat hukumnya adalah karena syarat dapat dilaksanakan akibat hukumnya belum dipenuhi, yaitu adanya kewenangan atas tindakan hukum yang dilakukan, dan adanya kewenangan atas objek akad;

d. Akad Nāfiż Gairu Lāzim. Akad Nāfiż artinya adalah akad yang sudah dapat diberlakukan atau dilaksanakan akibat hukumnya. Akad ini adalah lawan dari akad maukuf yang akibat hukumnya terhenti dan belum dapat dilaksanakan karena para pihak yang membuat tidak memenuhi salah satu syarat dalam berlakunya akibat hukum secara langsung, yaitu memiliki 
kewenangan atas tindakan dan atas objek akad, apabila kedua syarat ini telah dipenuhi, maka akadnya menjadi akad nāfiż.

\section{c. Konsep Waralaba}

Berdasarkan Pasal 1 ayat (1) Peraturan Pemerintah Nomor 42 Tahun 2007 tentang Waralaba, bahwa waralaba merupakan hak khusus yang dimiliki oleh orang perseorangan atau badan usaha terhadap sistem bisnis dengan ciri khas usaha dalam rangka memasarkan barang dan/atau jasa yang telah terbukti berhasil dan dapat dimanfaatkan dan/atau digunakan oleh pihak lain berdasarkan perjanjian waralaba. Berdasarkan Penjelasan Pasal 3 huruf (a) Peraturan Pemerintah Nomor 42 Tahun 2007, yang dimaksud dengan ciri khas usaha adalah suatu usaha yang memiliki keunggulan atau perbedaan yang tidak mudah ditiru, dibandingkan dengan usaha lain sejenis, dan membuat konsumen selalu mencari ciri khas dimaksud. Misalnya, sistem manajemen, cara penjualan dan pelayanan, atau penataan atau cara distribusi yang merupakan karakteristik khusus dari pemberi waralaba. Unsur-unsur yang dapat dirumuskan dari definisi di atas adalah: a) adanya hak khusus; b) pelakunya bisa perseorangan maupun badan usaha; c) adanya objek sistem bisnis dengan ciri khas usaha; dan d) tujuannya memasarkan barang dan/atau jasa yang telah terbukti berhasil dan dapat dimanfaatkan dan/atau digunakan oleh pihak lain; serta e) dasarnya perjanjian waralaba.

Menurut Salim HS (2003: 165), pengertian waralaba/franchise secara yuridis adalah suatu kontrak yang dibuat antara franchisor dan franchisee, dengan ketentuan pihak franchisor memberikan lisensi kepada franchisee untuk menggunakan merek barang atau jasa dalam jangka waktu tertentu dan pembayaran sejumlah royalty tertentu kepada franchisor. Pengertian tersebut mengandung beberapa unsur, yaitu: a) adanya subjek hukum, yaitu franchisor dan franchisee; b) adanya lisensi atas merek barang atau jasa; c) untuk jangka waktu tertentu; d) adanya pembayaran royalty. Senada dengan pengertian menurut konsultan waralaba Amir Karamoy, waralaba adalah suatu pola kemitraan usaha antara perusahaan yang memiliki merek dagang terkenal dan sistem manajemen, keuangan, dan pemasaran yang telah mantap, yang disebut pewaralaba, dengan perusahaan atau individu yang memanfaatkan atau menggunakan merek dan sistem bisnis milik pewaralaba, yang disebut terwaralaba. Pewaralaba wajib memberikan bantuan teknis, manajemen dan pemasaran kepada terwaralaba dan sebagai timbal baliknya, terwaralaba membayar sejumlah biaya (fee) kepada pewaralaba. Hubungan Kemitraan usaha antara kedua pihak dikukuhkan dalam suatu Perjanjian Lisensi atau Perjanjian Waralaba (dalam Marimbo, 2007: 4).

Bedasarkan definisi-definisi tersebut di atas maka dapat dipahami bahwa waralaba adalah kegiatan bisnis yang didasarkan perjanjian atau perikatan antara pemberi waralaba atau pewarlaba atau franchisor dengan pihak penerima waralaba atau terwaralaba atau franchisee. Perjanjian atau perikatan waralaba ini juga tunduk pada ketentuan hukum perjanjian atau perikatan yang ada dalam KUHPerdata seperti aturan tentang syarat sahnya perjanjian dan asas- asas perjanjian.

Akan tetapi di dalam hukum Islam Waralaba/Franchise tergolong bentuk perjanjian baru. Perjanjian franchise mempunyai persamaan dengan sistem ijārah 
(sewa-menyewa). Ijārah dapat diartikan sebagai suatu jenis akad untuk mengambil manfaat dengan jalan penggantian (Suhrawardi, 2004: 144). Secara terminologi, ada beberapa definisi ijārah yang dikemukakan para ulama fiqh. Ulama Mazhab Hanafi mendefinisikannya dengan "transaksi terhadap suatu manfaat dengan imbalan". Kemudian Ulama Mazhab Syafii menjelaskan ijärah adalah akad atas suatu manfaat tertentu, bersifat mubah dan boleh dimanfaatkan dengan kompensasi atau imbalan tertentu. Adapun Mazhab Maliki mengatakan, ijärah adalah perpindahan kepemilikan manfaat sesuatu yang dibolehkan dalam waktu tertentu dengan suatu kompensasi tertentu (Suhrawardi, 2004: 145). Berdasarkan beberapa definisi di atas, maka akad ijārah bisa diartikan sebagai akad pemindahan hak pakai atas barang atau jasa dalam waktu tertentu dengan suatu imbalan (upah sewa) yang tidak dikuti oleh pemindahan hak milik atas barang yang disewa. Ijarāh tersebut sama dengan sistem dalam perjanjian waralaba.

Bisnis waralaba syariah merupakan sebuah konsep kerja sama yang menguntungkan antara dua pihak dalam mengembangkan usaha masing-masing, baik franchisor maupun franchisee (Suseno, 2008: 13). Hal ini sesuai dengan firman Allah yang berbunyi: "Dan tolong-menolonglah kamu dalam (mengerjakan) kebajikan dan taqwa dan jangan tolong menolong dalam berbuat dosa dan pelanggaran. Dan bertaqwalah kamu kepada Allah, sesungguhnya Allah amat berat siksa-Nya" (QS. Al Maidah: 2). Demikian pula di dalam QS. Shaad: 24, "Dan sesungguhnya kebanyakan dari orang-orang yang berserikat itu sebagian mereka berbuat zalim kepada sebagian yang lain, kecuali orang-orang yang beriman dan mengerjakan amal yang saleh, dan amat sedikitlah mereka ini." Selanjutnya Rasulullah menerangkan sisi positif dari berserikat ini yaitu dalam hadis Qudsi dari Abu Hurairah Ra, bersabdalah Rasulullah Saw "sesungguhnya Allah Swt berkata: "Aku adalah yang ketiga (penolong) dari dua orang yang berserikat, selama salah satunya tidak menghianati kawannya, apabila ia berhianat maka Aku keluar dari perserikatan dua orang itu" (HR. Abu Dawud No. 3383) (Budi, 2008: 14).

Fikih Islam memberi penilaian terhadap konsep waralaba berdasarkan dasar hukum yang telah dijelaskan di atas bahwa waralaba memiliki konsep yang setara dengan konsep syirkah, konsep ijārah dan juga konsep ibtikār. Waralaba dilihat dari teori syirkah; secara etimologi syirkah berarti percampuran, yaitu percampuran antara sesuatu dengan yang lainnya, sehingga sulit dibedakan. Syirkah termasuk salah satu bentuk kerjasama dagang dengan rukun dan syarat tertentu, yang dalam hukum positif disebut dengan perserikatan dagang. Syirkah atau musyārakah adalah akad kerja sama antara dua pihak atau lebih untuk suatu usaha tertentu dimana masingmasing pihak memberikan kontribusi dana dengan kesepakatan bahwa keuntungan dan resiko akan ditanggung bersama sesuai dengan kesepakatan. Berdasarkan beberapa definisi tersebut, subtansi akad syirkah adalah ikatan (kontrak) kerja sama yang dilakukan dua orang atau lebih dalam usaha bisnis atau perdagangan keuntungan dan keruginnya ditanggung bersama (Hasan, 2003: 163-165). Akad syirkah diperbolehkan berdasarkan firman Allah Swt dalam QS. Shād: 24, “...sesungguhnya kebanyakan dari orang-orang yang berserikat itu sebagian mereka 
berbuat zalim kepada sebagian lain, kecuali orang-orang yang beriman dan mengerjakan amal-amal saleh, dan amat sedikit mereka ini". Subtansi akad yang mengarah atau mendekati akad syirkah yaitu terbentuknya kerja sama dalam usaha bisnis dengan berbagi keuntungan, yang dalam bisnis waralaba juga terdapat suatu bentuk kerjasama antara franchisor dan franchisee dalam menjalankan bisnis untuk memperoleh keuntungan bersama (Hasan, 2003: 166).

Jika waralaba dilihat dari teori ijārah, maka ijārah dalam Bahasa Arab berarti upah, sewa, jasa, atau imbalan. Ijārah merupakan salah satu bentuk kegiatan muamalah dalam memenuhi keperluan hidup manusia, seperti sewa menyewa, kontrak, atau menjual jasa perhotelan dan lain-lain. Ulama Mazhab Hanafi mendefinisikan ijärah adalah transaksi terhadap suatu manfaat dengan imbalan. Ulama Mazhab Syafii menjelaskan bahwa ijärah adalah akad atas suatu manfaat tertentu, bersifat mubah dan boleh dimanfaatkan dengan kompensasi atau imbalan tersebut. Akad ijārah dalam QS. Al-Baqarah: 233 disebutkan, "dan jika kamu ingin anakmu disusukan oleh orang lain, tidak dosa bagimu apabila kamu memberikan pembayaran menurut yang patut. Bertaqwalah kepada Allah, dan ketahuilah bahwa Allah Maha melipat gandakan apa yang kamu kerjakan" (Hasan, 2003: 227-229). Ayat tersebut menunjukan kebolehan seseorang menyewa jasa orang lain untuk menyusui anaknya, dengan syarat membayar upah secara layak. Ungkapan ini menunjukan adanya jasa orang lain yang diberikan, dan adanya kewajiban membayar yang patut atas jasa yang diterima. Salah satu isi subtansi kontrak bisnis waralaba adalah pemberian lisensi (ijin) oleh franchisor kepada franchisee untuk memanfaatkan atau menggunakan Hak Kekayaan Intelektual (HKI) atau ciri khas franchisor di dalam menjalankan bisnisnya dengan imbalan sejumlah royalty yang harus dibayar oleh franchisee dalam batas waktu tertentu. Subtansi kontrak bisnis waralaba tersebut tidak jauh berbeda dengan subtansi akad ijārah dalam hukum Islam yaitu sama-sama memindahkan kepemilikan manfaat atas benda ataupun jasa dengan imbalan sejumlah uang dalam batasan waktu tertentu. Oleh karena itu konsep waralaba setara dengan konsep akad ijārah.

Waralaba dilihat dari konsep Ibtikār; secara etimologi ibtikār berarti awal sesuatu atau permulaan. Ibtikār dalam Fikih Islam dimaksudkan adalah hak cipta/kreasi yang dihasilkan seseorang untuk pertama kali. Ibtikār atau hak cipta terbilang hal yang baru dalam kajian fikih, hak cipta secara maknawi merupakan kepemilkan khusus dan merupakan hasil karya intelektual manusia yang sudah selayaknya ada penghargaan khusus dari masyariahat umum baik dari segi moral maupun finansial. Salah satu aspek hukum bisnis waralaba adalah obyek kontrak yang berupa Hak Kekayaan Intelektual (HKI). Hak Kekayaan Intelektual, dilihat dari sudut hukum Islam menyangkut masalah hak cipta yang meliputi merek dagang atau jasa, logo, sistem operasional bisnis yang terpadu yang menjadi ciri khas usaha franchisor. Persoalan yang muncul terkait dengan hak cipta dalam hukum Islam menyangkut status kepemilikan bagi pemiliknya dan hukum yang melingkupinya dalam pandangan fikih muamalat. Para ulama fikih sepakat menyatakan bahwa hak kepemilikan mubtakir (pemikir dan pencipta suatu kreasi) terhadap hasil pemikiran 
dan ciptaannya adalah milik yang bersifat material. Oleh sebab itu, hak ibtikār apabila dikaitkan dengan tabiat harta dapat ditransaksikan, dapat diwarisi jika pemiliknya meninggal dunia, dan dapat dijadikan wasiat jika seseorang ingin berwasiat. Dengan demikian hak cipta/kreasi memenuhi segala harta-harta lainnya yang halal. Para ulama fikih mnyatakan bahwa hak cipta atau kreasi seseorang harus mendapatkan perlindungan hukum yang sama dengan harta lainnya (Hasan, 2003: 150-154)

Hak untuk memanfaatkan atau Hak Kekayaan Intelektual (HKI) dalam konteks bisnis waralaba dimiliki oleh franchisee atau ijin (lisensi) dari franchisor sama dengan konteks yang dimiliki oleh akad ibtikār. Seseorang berhak mengembangkan atau mendistribusikan hartanya. Salah satu caranya adalah dengan cara waralaba. Pemilik lisensi memberikan izin kepada pihak lain untuk menggunakan merek dagang suatu produk untuk diperdagangkan dengan membuat suatu perjanjian.

\section{d. Bagi Hasil}

Islam memaknai bunga sebagai riba yang diharamkan oleh syariah. Sehingga bunga tidak ditetapkan dalam ekonomi berbasis syariah dan sebagai gantinya diterapkan sistem bagi hasil. Bagi hasil menurut istilah adalah suatu sistem yang meliputi tata cara pembagian hasil usaha antara penyedia dana dan pengelola dana (Rofiq, 2004: 153). Menurut terminologi asing (Inggris) bagi hasil dikenal dengan profit sharing. Profit sharing dalam kamus ekonomi diartikan sebagai distribusi beberapa bagian dari laba (profit) pada para pegawai dari suatu perusahaan (Pass, et al, 1997: 537). Lebih lanjut dikatakan, bahwa hal itu dapat berbentuk suatu bonus uang tunai tahunan yang didasarkan pada laba yang diperoleh pada tahun-tahun sebelumnya, atau dapat berbentuk pembayaran mingguan atau bulanan. Jika dalam suatu perusahaan, maka perolehan bagian laba sering dianjurkan untuk meningkatkan tanggung jawab pegawai dan dengan demikian meningkatkan produktifitas (Muhammad, 2001: 23).

Pendapatan bagi hasil berlaku untuk produk-produk penyertaan, baik penyertaan menyeluruh maupun sebagian, atau bentuk bisnis korporasi (kerja sama). Pihak-pihak yang terlibat dalam kepentingan bisnis yang disebut tadi, harus melakukan transparansi dan kemitraan secara baik dan ideal, sebab semua pengeluaran dan pemasukan rutin untuk kepentingan pribadi yang menjalankan proyek (Muhammad, 2001: 15). Keuntungan yang dibagi hasilkan harus dibagi secara proporsional antara shāhibul māl dengan muḍarrib. Dengan demikian, semua pengeluaran rutin yang berkaitan dengan bisnis muḍärabah, bukan untuk kepentingan pribadi mudharib, dapat dimasukkan ke dalam biaya operasional. Keuntungan bersih harus dibagi antara shāhibul māl dan muḍarrib sesuai dengan proporsi yang disepakati sebelumnya dan secara eksplisit disebutkan dalam perjanjian awal. Tidak ada pembagian laba sampai semua kerugian telah ditutup dan equiti shahibul maal telah dibayar kembali. Jika ada pembagian keuntungan sebelum habis masa perjanjian akan dianggap sebagai pembagian keuntungan di muka.

Adapun metode penghitungan bagi hasil dapat dilakukan dengan dua macam pendekatan, yaitu: 
a. Pendekatan bagi laba, adalah hitungan bagi hasil yang berdasarkan pada laba dari pengelola dana, yaitu pendapatan usaha dikurangi dengan biaya usaha untuk memperoleh pendapatan tersebut.

b. Pendekatan bagi pendapatan, adalah penghitungan laba didasarkan pada pendapatan yang diperoleh dari pengelola dana, yaitu pendapatan usaha sebelum dikurangi dengan biaya usaha untuk memperoleh pendapatan tersebut.

Oleh karena itu, Ekonomi Syariah menjabarkan konsep pembagian hasil sebagai berikut:

a. Pemilik dana menanamkan dananya melalui lembaga keuangan yang bertindak sebagai pengelola dana

b. Pengelola mengelola dana tersebut dengan sistem yang dikenal dengan sistem penghimpunan dana, selanjutnya pengelola dana menginvestasikan dana-dana tersebut ke dalam usaha yang layak menguntungkan dan yang memenuhi ketentuan aspek syariah.

c. Kedua belah pihak membuat kesepakatan (akad) yang berisi ruang lingkup kerja sama, jumlah nominal dana, nisbah, dan jangka waktu berlakunya kesepakatan.

Dengan demikian yang menjadi inti mekanisme investasi bagi hasil pada dasarnya adalah terletak pada kerjasama yang baik antara shahibul maal dengan mudharib. Kerjasama atau partnership merupakan karakter dalam masyariahat ekonomi Islam. Kerjasama ekonomi harus dilakukan dalam semua lini kegiatan ekonomi, yaitu: produksi, distribusi barang maupun jasa. Salah satu bentuk kerjasama dalam bisnis atau ekonomi Islam adalah qiraḍ atau muḍārabah. Qiraḍ atau muḍārabah adalah kerjasama antara pemilik modal atau uang dengan pengusaha pemilik keahlian atau ketrampilan atau tenaga dalam pelaksanaan unit-unit ekonomi atau proyek usaha. Melalui qiraḍ atau muḍarrabah kedua belah pihak yang bermitra tidak akan mendapatkan bunga, tetapi mendapatkan bagi hasil atau profit dan loss sharing dari proyek ekonomi yang disepakati bersama (Muhammad, 2001: 18).

\section{Sistem bagi Hasil dalam Perjanjian Waralaba Perspektif Hukum Islam}

Pada perjanjian waralaba yang dijalankan sesuai syariat, tujuan utamanya adalah kemaslahatan atau kesejahteraan pihak-pihaknya bahwa dengan melakukan usaha melalui perjanjian tersebut terjadi keuntungan di antara keduanya yaitu pihak shāhibul māl (penerima waralaba/pemberi modal) dapat memperoleh keuntungan dari modal diberikannya kepada muḍarrib (pemberi waralaba), sedangkan mudarrib/franchisor dapat menjalankan usahanya melalui modal tersebut. Hasil penelitian yang didapatkan dari kajian ini adalah sebagai berikut:

\section{a. Kebab Turki Baba Rafi}

Kebab Turki Baba Rafi merupakan salah satu waralaba (franchise) berdasarkan sistem syariah. Hal ini sebagaimana dijelaskan oleh Hendy Setiono (franchisor), bahwa Kebab Turki Baba Rafi merupakan salah satu bisnis waralaba yang 
menerapkan sistem Syariah di mana pihak franchisee (penerima waralaba) menginvestasikan modalnya kepada pihak franchisor (pemberi waralaba) untuk mengelola outlet Kebab Turki Baba Rafi dengan sistem bagi hasil (profit sharing) sebesar 50:50. Menurut franchisor, franchisee dibebaskan dari royalty fee setiap bulan namun royalty fee dikenakan pada laba bersih sebesar 3\%, bagi hasil juga dikenakan terhadap laba bersih dari omzet penjualan kebab.

Investasi atau modal awal sejumlah Rp 65.000.000 yang diserahkan franchisee Kebab Turki Baba Rafi kepada franchisor untuk kemudian dengan modal tersebut membuka outlet Kebab Turki yang dikelola oleh pemberi waralaba/franchisor dengan tujuan memperoleh profit/keuntungan. Keuntungan (laba bersih) yang diperoleh tersebut dibagi dua dengan nisbah keuntungan sebesar 50:50. Contoh pembagian keuntungan misalnya, pada bulan Agustus memperoleh keuntungan sebesar Rp 3.000.000 maka nominal pembagian keuntungan adalah pemberi waralaba/ franchisor Rp 1.500.000 dan penerima waralaba/franchisee sebesar Rp 1.500.000, jika pada bulan Juli memperoleh keuntungan sebesar Rp 2.000.000 maka franchisor dan franchisee masing-masing menerima Rp 1.000.000. Secara terperinci keuntungan dan ketentuan waralaba Kebab Turki Baba Rafi dapat dideskripsikan sebagai berikut:

1) Keuntungan bagi franchisee yaitu, bebas royalty fee setiap bulan; outlet dikelola penuh oleh franchisor; keuntungan lebih terjamin; dan sistem kerjasama profit sharing 50:50 setiap bulan.

2) Ketentuan bahwa, seluruh biaya pengelolaan outlet (BPO) dibebankan pada total omzet; dan biaya pengelolaan outlet tersebut meliputi: a) pemakaian bahan baku (termasuk packaging); b) komisi dan gaji pegawai; c) sewa tempat; d) transportrasi kurang lebih Rp 10.000/hari; e) biaya operasional, seperti gas LPG, perbaikan atau penambahan perlengkapan outlet; f) laba bersih diperoleh dari total omzet dikurangi BPO; g) franchisee menyediakan fasilitas sepeda motor untuk operasional operator outlet; dan h) jangka waktu waralaba 4 tahun dan dapat diperpanjang. Dari ketentuan tersebut, dapat disimpulkan bahwa jika terdapat hutang maka hutang itu termasuk BPO yang dapat dikurangkan pada total omzet.

Melihat sistem yang diterapkan oleh Kebab Turki Baba Rafi ini pembagian keuntungan dalam perjanjian waralaba (franchise) menggunakan sistem mudāabah, yaitu kekuasaan pengelolaan sepenuhnya berada di pihak pemberi waralaba (franchisor) yang sekaligus merangkap sebagai pengelola modal (mudarrib).

\section{b. Quantum Student}

Quantum Student juga menerapkan konsep usahanya dengan sistem franchise Syariah atau kemitraan berbentuk syirkah muḍarabah dengan bentuk kerja sama bagi hasil keuntungan bersih (net margin) sebesar 50:50 atau 60:40 dari hasil yang diperoleh tiap bulannya dari pembayaran para siswa bimbingan belajar, antara lembaga pendidikan Quantum Student sebagai pengelola (fanchisor) investor (franchisee). Dari investasi sebesar Rp 200.000.000, franchisee memperoleh sarana 
dan prasarana serta biaya perkiraan tempat. Sarana dan prasarana yang diperoleh franchisee berupa pengajar, buku panduan, peralatan multimedia, peralatan pendidikan, perlengkapan marketing (brosur, spanduk, dll), dan papan nama. Quantum Student tidak memberlakukan pembayaran franchisee fee dan royalty fee setiap bulannya selama perjanjian untuk jangka waktu lima tahun dan dapat diperpanjang kembali.

Melalui nilai investasi awal sebesar Rp 200.000.000, pihak franchisor/pemberi waralaba akan mengelola modal tersebut menjadi lembaga pendidikan dengan nama dagang "Quantum Student". Pengelolaan dengan sistem perwakilan dari salah satu pihak (dalam hal ini pihak mudarrib/franchisor) dengan ketentuan yang telah disepakati dan pembagian keuntungan yang jelas dengan perincian mudarrib 60\% serta shāhibul māl/ franchisee sebesar 40\% atau 50:50 yang diambilkan dari laba bersih.

Berdasarkan penjelasan di atas dapat dipahami bahwa pembagian keuntungan perjanjian waralaba menurut hukum Islam adalah persentase (nisbah) dan pembagian keuntungan untuk masing-masing pihak yang berserikat ini dijelaskan pada saat berlangsungnya akad. Keuntungan yang dimaksud merupakan keuntungan yang diambilkan dari hasil laba bersih usaha yang dikelola oleh pemberi waralaba/franchisor dan bukan dari harta lain. Jikalau terdapat hutang akan dikurangkan pada hasil keuntungan/laba sebelum dibagikan antara pihak muḍarrib dan shāhibul māl berdasarkan akad. Dengan demikian sistem pembagian keuntungan/bagi hasil yang diterapkan pada Quantum Student tersebut termasuk dalam jenis bagi hasil muḍarrabah, yaitu akad kerja sama antara pemilik dana dan pihak pengelola yang keuntungan bagi hasilnya dibagi sesui nisbah yang telah disepakati pada saat berlangsungnya akad. Oleh karena itu konsep waralaba Syariah merupakan sistem pembagian keuntungan dengan menggunakan sistem bagi hasil/muḍārabah. Sistem muḍārabah inilah yang di dalam Islam justru yang diperbolehkan. Hal tersebut di dalam Al-Quran disebutkan dalam QS Al-Muzammil: 20, “...dan dari orang-orang yang berjalan di muka bumi mencari sebagian karunia Allah SWT..."

Selain itu di dalam Hadis Shalih bin Shuhaib Ra. bahwa Rasulullah Saw. bersabda, "tiga hal yang di dalamnya terdapat keberkahan: jual beli secara tangguh, muqāraḍh (muḍ̄rabah) dan mencampur gandum dengan tepung untuk keperluan rumah bukan untuk dijual" (HR. Ibnu Majah). Dengan demikian waralaba Syariah dengan menggunakan sistem bagi hasil muḍārabah diperbolehkan dalam Syariah Islam dan tidak bertentangan dengan Hukum Islam. Hal ini berbanding terbalik dengan franchise yang sering digunakan dalam hukum perdata atau secara konvensional, dalam perjanjian waralaba menurut prespektif hukum perdata tidak terdapat pembagian keuntungan, pihak franchisee mencari besarnya keuntungan dengan pengelolaan sendiri, sedangkan franchisor hanya memasok kebutuhan pengelolaan barang dan/atau jasa yang dibutuhkan franchisee.

\section{Kendala dalam Pembagian Keuntungan pada Perjanjian Waralaba Perspektif Hukum Islam dan Penyelesaian Sengketa.}


Berdasarkan hasil wawancara dengan responden bahwa kendala pada pembagian keuntungan dalam perjanjian waralaba pada umumnya terjadi karena tidak terpenuhinya hak dan kewajiban para pihak (wanprestasi). Berikut penulis temukan kendala dan penyelesaiannya, yaitu:

a. Jika terjadi kerugian, sering menjadi pokok perselisihan/sengketa yang mengarah pada siapa yang berkewajiban menanggung kerugian tersebut atau pantas tidaknya salah satu pihak menanggung terjadinya kerugian, karena merasa terjadinya kerugian bukan karena kesalahan atau kelalaiannya. Menurut responden Hendy (franchisor Kebab Turki), apabila terjadi kerugian maka akan diganti dengan laba yang diperoleh, setelah laba dikurangi beban kerugian atau biaya ganti rugi maka laba bersih baru dibagi sesuai persentase yang disepakati yaitu 50:50. Penyelesaian sengketa dapat dilakukan dengan jalan musyawarah untuk menemukan jalan tengah dari kendala/permasalahan tersebut. Selain itu, waralaba yang dijalankan menurut sistem Islam akan meminimalisir sengketa yang timbul karena dalam perjanjian tersebut ada keseimbangan hak dan kewajiban (M. Hafidz, franchisor Quantum Student).

b. Prestasi yang diterima tidak seimbang. Setiap franchisee pasti menginginkan investasinya berkembang dan memperoleh keuntungan, namun karena awamnya franchisee dalam mengelola penjualan, maka tak jarang sebagai franchisee dirinya mengalami kerugian. Kerugian tersebut tentunya akan ditanggung oleh franchisee sendiri karena franchisor merupakan penyedia peralatan operasional dan sistem waralaba saja sedangkan pengelolaan waralaba sepenuhnya merupakan tanggungjawab franchisee. Permasalahan yang sering terjadi adalah apabila franchisee tidak dapat mengembangkan usahanya dan tidak balik modal atau terjadi kerugian, maka franchisee tidak dapat menuntut apapun dari franchisor. Permasalahan ini biasa ditemui dalam perjanjian waralaba yang dikelola secara konvensional, bukan mudārabah. Sebab hal itu termasuk dalam kesepakatan bersama yang harus dipenuhi dan ditepati. Jika melanggar harus menanggung akibatnya dan menjamin kerugian yang menimpa modal atau kepentingan pemilik modal/franchisee. Franchisor adalah seorang wakil dari sāhibul māl dalam menjalankan modal, maka tindakan yang terkait dengan pembagian keuntungan/muḍārabah harus sesuai dengan ketentuan atau syarat yang ditetapkan oleh pemilik modal. Dalam perspektif hukum Islam ganti kerugian dapat ditanggung oleh kedua belah pihak dengan ganti kerugian yang diambil dari laba bersih.

c. Pembagian keuntungan yang kurang transparan atau tidak sesuai dengan waktu yang ditentukan. Menurut M. Hafidz (franchisor Quantum Student), bahwa yang menjadi persoalaan dalam pembagian keuntungan adalah jumlah laba bersih yang akan dibagikan, karena laba tersebut diperoleh dari omzet dikurangi biaya produksi. Seringnya biaya produksi yang tidak 
tercatat atau dibukukan akan mengurangi transparasi keuntungan yang diperoleh.

d. Sanksi bagi pengelola/franchisor (Mudarrib) tergantung pada kesepakatan yang telah dibuat. Sebab hal itu termasuk dalam kesepakatan bersama yang harus dipenuhi dan ditepati, maka jika melanggar harus menanggung akibatnya dan menjamin kerugian yang menimpa modal atau kepentingan pemilik modal/franchisee, sebab franchisor adalah seorang wakil dari sāhibul māl dalam menjalankan modal, maka tindakan yang terkait dengan pembagian keuntungan/ mudārabah harus sesuai dengan ketentuan atau syarat yang ditetapkan oleh pemilik modal.

\section{KESIMPULAN dan SARAN}

\section{Kesimpulan}

a. Menurut perspektif hukum Islam, keuntungan yang dihasilkan dalam perjanjian waralaba dibagi menggunakan sistem bagi hasil. Adapun persentase bagi hasil yang digunakan yaitu 50:50 atau 60:40 tergantung dari kesepakatan para pihak, yaitu muḍarrib/franchisor dan sāhibul māl/franchisee.

b. Kendala yang sering timbul pada pembagian keuntungan dalam perjanjian waralaba yaitu, jika terjadi kerugian dan juga jika terjadi ketidakseimbangan antara prestasi yang diberikan dengan pembagian keuntungan yang kurang transparan.

c. Penyelesaian kendala dalam pembagian keuntungan dalam perjanjian waralaba perspektif hukum Islam dapat ditempuh dengan musyawarah mufakat, selain itu dapat pula diikuti dengan pembayaran ganti rugi. 


\section{Saran}

a. Bagi Fanchisor

Untuk menghindari masalah dalam pelaksanaan perjanjian bisnis waralaba, franchisor hendaknya selektif terhadap para calon franchisee. Kandidat calon franchisee hendaknya telah terkualifikasi dengan baik. Seyogyanya, franchisor tidak hanya melihat dari sisi kuantitas dan kualitas modal semata, namun juga melakukan langkah-langkah preventif seperti pembuatan kontrak yang mudah dipahami oleh calon franchisee yang mengatur secara jelas tentang hak dan kewajiban kedua belah pihak, sehingga jika dirasa terjadi ketidak sesuaian dalam pelaksanaan perjanjian, maka perjanjian (akad) yang telah dibuat tersebut tinggal diimplementasikan. Di samping itu perlu adanya mekanisme kontrol yang memadai.

b. Bagi Franchisee

Franchisee seyogyanya memahami isi akad, karena pada umumnya format bisnis waralaba harus mengikuti prosedur yang ditentukan pemberi waralaba. Agar dalam pelaksanaanya tidak ada pihak yang merasa dihianati oleh salah pihak, misalnya merasa dalam pembagian keuntungan tidak seimbang dan/atau kurang transparan.

\section{A. Buku-buku}

\section{DAFTAR PUSTAKA}

Rofiq, Ahmad (2004). Fiqih Kontekstual dari Normatif ke Pemaknaan Sosial. Yogyakarta: Pustaka Pelajar

Karamoy, Amir (2011). Waralaba (Jalur Bebas Hambatan Menjadi Pengusaha Sukses). Jakarta: Gramedia.

Pasaribu, Chairuman dan Lubis, Suhrawardi K. (2004). Hukum Perjanjian Dalam Islam, Jakarta: Sinar Grafika.

Suseno Budi, Darmawan (2008). Waralaba Syariah. Jakarta: Cakrawala.

Dewi, Gemala (2001). Hukum Perikatan Islam di Indonesia. Jakarta: Kencana.

Muljadi, Kartini dan Widjaja, Gunawan (2010). Perikatan yang Lahir dari Perjanjian, Jakarta: Rajawali Pres.

Hasan, M. Ali (2003). Berbagai Macam Transaksi dalam Islam. Jakarta: Raja Grafindo.

Badrulzaman, Mariam Darus (2001). Kompilasi Hukum Perikatan. Bandung: Citra Aditya Bakti.

Muhammad (2001). Teknik Perhitungan Bagi Hasil di Bank Syari'ah. Yogyakarta: UII Press.

Marimbo, Rizal Calvary (2007). Rasakan Dahsyatnya Usaha Franchise. Jakarta: Elex Media Komputindo (Gramedia Group). 
Soemitro, Ronny Hanitijo (1994). Metodologi Penelitian Hukum Dan Jurimetri. Jakarta: Ghalia Indonesia.

Salim (2002). Pengantar Hukum Perdata Tertulis (BW). Jakarta: Sinar Graham. (2003). Perkembangan Hukum Kontrak Innominaat di Indonesia. Jakarta: Sinar Grafika.

Soekanto, Soerjono (2005). Pengantar Penelitian Hukum. Jakarta: Universitas Indonesia.

Subekti (2004). Hukum Perjanjian. Jakarta: Intermasa.

Mertokusumo, Sudikno (2003). Mengenal Hukum Suatu Pengantar. Yogyakarta: Liberty.

Lubis, Suhrawardi K. (2004). Hukum Ekonomi Islam. Jakarta: Sinar Grafika.

Anwar, Syamsul (2007). Hukum Perjanjian Syariah. Jakarta: Raja Grafindo Persada.

\section{B. Peraturan}

Al-Quran dan Hadis

Kitab Undang-Undang Hukum Perdata

Peraturan Pemerintah No. 42 Tahun 2007 Tentang Waralaba 